\title{
ОСОБЛИВОСТІ ПРАВ ЗАСУДЖЕНИХ, ЯКІ ВІДБУВАЮТЬ ПОКАРАННЯ У ВИГЛЯДІ ПОЗБАВЛЕННЯ ВОЛІ
}

\author{
БОРТНИК Надія Петрівна - завідувач кафедри адміністративного та \\ інформаційного права Національного університету «Львівська політехніка», \\ доктор юридичних наук, професор \\ КАПІТАН Ольга Ігорівна - асистент кафедри права Львівського \\ національного університету ветеринарної медицини та біотехнологій імені \\ C. 3. Гжицького, PhD
}

УДК 342.343.8.01(477)

DOI $10.32782 / N P .2020 .4 .5$

\begin{abstract}
В статье рассмотренъ вопросъи классификации прав осужденнъх, отбъвающих наказание в виде лишения свободъ, в контексте национальных и международнъхх норм реализаиии прав, на основе современнъих научных подходов к классификации нормативно-правовых актов в сбере обеспечения прав человека, определения основных составляюших нормативной базъ уголовно-исполнительного права в контексте регулирования и защить прав граждан, осужденных к лишению свободъ в Украине. Рассмотренъ основные положения уголовно-правового законодательства, определяюшие содержание правового статуса осужденных и составляющие его структуру. Осуществлен анализ правовых основ статуса осужденнъхх к лишению свободъ в Украине, определень общегражданские и специильные права осужденных клишению свободъи.

Ключевъе слова: права, осужденнъии, лишение свободь, правовой статус, учреждение исполнения наказаний, международнъие стандарты, иностраниъл.
\end{abstract}

Постановка проблеми

Правовий статус засуджених, які відбувають покарання у вигляді позбавлення волі, є складним поняттям. Вихідні положення правового статусу засуджених до позбавлення волі визначаються в приписах міжнародних правових актів, базуються на загальному правовому статусі громадян України (зазначеному в Кон- ституції), встановлені кримінально-виконавчим законодавством України. 3 огляду на це, вивчення прав осіб, засуджених до покарання, пов'язаного з позбавленням волі, є одним 3 основних питань адміністративного i кримінально-виконавчого права. Закріплення прав і свобод людини в Конституції України стосуються кожного громадянина, в тому числі засуджених, які відбувають покарання в місцях позбавлення волі на території України.

Аналіз останніх публікацій

Дослідженням класифікації прав засуджених, які відбувають покарання у вигляді позбавлення волі у юридичній науці займаються науковці: О. М. Литвинов, I. Г. Богатирьов, А. X. Степанюк, I. С. Яковець, К. А. Автухов, А. П. Гель, О. Г. Колб, Н. В. Коломієць та ін. Европейська інтеграція України ставить завдання щодо приведення національного законодавства до вимог Свропейського Союзу у всіх сфеpax життедіяльності суспільства, зокрема й у сфері, що досліджується.

Мета статті - дослідження класифікації прав засуджених, які відбувають покарання у вигляді позбавлення волі.

Виклад основного матеріалу

Правовий статус засуджених до позбавлення волі, будучи спеціальним і похідним від загального правового статусу особи, $\epsilon$ сукупністю суб'єктивних прав, свобод, за- 


\section{Адміністративне право}

конних інтересів і юридичних обов'язків, встановлених кримінально-виконавчим законодавством України, іншими законами та гарантованих державою під час відбування кримінального покарання у вигляді позбавлення волі. В основі правового статусу лежить фактичний соціальний статус, реальний стан засудженого, а право як соціальний регулятор закріплює це положення, вводить його в законодавчі рамки. Сутність правового статусу засуджених до позбавлення волі виражається у вилученні та обмеженні деяких прав і свобод, наділенні спеціальними правами, властивими покаранню у вигляді позбавлення волі.

На думку А. С. Колоса, елементами змісту правового статусу є суб'єктивні права, законні інтереси та обов'язки засуджених, а зміст суб'єктивних прав становлять можливість: засудженого вільно користуватися соціальними благами у межах, встановлених правом; вимагати виконання відповідних обов'язків адміністрацією органів і установ виконання покарань, іншими суб'єктами кримінально-виконавчих та інших правовідносин; звернутися за захистом суб'єктивного права [1, с. 107].

Учені виділяють такі види правового статусу засудженого: загальний, або конституційний; спеціальний, або родовий; особливий, або видовий; індивідуальний. Ю. В. Корнякевич-Танасійчук зазначає, що зазначені статуси співвідносяться як загальне, окреме та одиночне [2, с. 144].

Правовий статус засуджених є спеціальним статусом, властивим тільки цій групі громадян. Встановлюючи його, держава бере обов'язок не тільки виконати покарання, а й забезпечувати права засуджених. Принципове значення в теоретичному визначенні поняття «правовий статус» засуджених набуває питання про включення в нього поняття «права».

Права людини - це поняття, що характеризує правовий статус людини щодо держави, його можливості та домагання в економічній, соціальній, політичній і культурній сферах. Особливістю прав людини $\epsilon$ те, що вони носять природний і невідчужуваний характер, виступають відобра- женням невід'ємних властивостей кожної людини й істотних ознак її буття.

Проблема встановлення конституційних обмежень є проблемою меж свободи людини в суспільстві. Обмеження прав i свобод людини є необхідною складовою правової системи будь-якої держави та сучасного суспільства, що об'єктивно зумовлюе його законодавче врегулювання і створення окремого інституту права міжгалузевого характеру [3, с. 45].

Позбавлення волі, будучи покаранням за вчинений злочин і формою державного примусу, посягає на сферу прав засудженого, обмежує в правах і свободах і покладає додаткові обов'язки. Характер і кількість обмежень прав і свобод засуджених, які відбувають покарання у вигляді позбавлення волі (далі - засуджені), не можуть довільно визначатися законодавством, а безпосередньо повинні співвідноситися 3 положеннями Конституції України, міжнародних норм і стандартів поводження 3 ув'язненими. Міжнародні стандарти визнають право засуджених до позбавлення волі на гуманне ставлення та повагу їхньої людської гідності основоположним правом, яке створює підгрунтя для реалізації усіх інших прав, передусім з правом на соціальну адаптацію після відбування покарання [4, с. 122].

O. В. Краснокутський зазначає, що міжнародні механізми забезпечують не всі права засудженого, а лише ті з них, які мають ознаки статусоутворюючих, тобто права, що властиві особам, які набули статусу засудженого, відповідно, формують цей специфічний статус [5, с. 176].

Права засуджених до позбавлення волі в законодавстві України формулюються, виходячи із загальних принципів положення людини і громадянина в суспільстві та державі.

Особливості правового статусу засуджених визначаються тим, що останні відповідно до закону зобов'язані зазнати низки правових обмежень, наділяються специфічними правами. Особи, які відбувають покарання у вигляді позбавлення волі, можуть бути обмежені в реалізації конституційних прав відповідно до Кон- 
ституції України, згідно з якою права і свободи людини та громадянина можуть бути обмежені законом тільки в тій мірі, в якій це необхідно з метою захисту основ конституційного ладу, моральності, здоров'я, прав і законних інтересів інших осіб, забезпечення оборони і безпеки держави.

Норми кримінально-виконавчого права відносно кримінального права є процесуальними, оскільки вони забезпечують реалізацію кримінально-правових обмежень. Процесуальний характер виражається в організаційному забезпеченні реалізації прав суб'єктів кримінально-виконавчих правовідносин. Засуджені не виключаються в повному обсязі зі сфери правовідносин. Частину загальногромадянських прав засуджені можуть реалізувати в повному обсязі, інші в обмеженому, виходячи iз специфіки призначеного покарання i умов відбування в певних видах виправної установи. Специфічні суб'єктивні права та обов'язки засуджених, які одночасно виступають формами обмежень прав, що є елементами загального правового статусу, є тими індикаторами, що визначають спеціальний правовий статус засудженого i складають основне «ядро» його змісту [6, c. 26].

Права засуджених діляться на загальногромадянські та спеціальні. Загальногромадянські права можна розділити на дві групи: права, що не обмежуються; права, які порушуються частково.

Врахування специфіки відбування покарання у вигляді позбавлення волі показує, що засуджені наділені загальногромадянськими правами не в повному обсязі. У деяких загальногромадянських правах засуджені обмежені повністю (політичні права, право на свободу пересування, на вибір місця перебування та проживання).

Під спеціальними правами засуджених до позбавлення волі необхідно розуміти сукупність прав, обумовлених статусом засудженого та сутністю позбавлення волі як ізоляції від суспільства, режимом і умовами відбування покарання. Серед них варто виділяти загальні і особливі права. Загальні, властиві всім засудженим до по- збавлення волі, а особливі - засудженим до позбавлення волі певної категорії.

Загальногромадянські права, що не обмежуються. До цих прав відноситься сукупність невідчужуваних прав, що належать людині від народження та не залежать від належності до конкретної держави. До них зараховують: право на життя; право не піддаватися жорстокому, такому, що принижує людську гідність, поводженню чи покаранню, а також тортурам; право на судовий захист і правосуддя; право на гідність особи; право на звернення; право на соціальне забезпечення; право на охорону здоров'я та отримання медичної допомоги.

Право на життя - це основне природне, невід'ємне приватне право, людини. Цим правом наділені всі громадяни, в тому числі й засуджені. Воно не піддається обмеженню з боку законодавства, а, навпаки, охороняється на всіх рівнях - національному, регіональному.

Право на особисту безпеку засуджених під час виконання кримінальних покарань є базисним правом, гарантованим законодавством, що забезпечує відсутність небезпек. Гарантування безпеки особи у виправних установах обумовлено об'єктивною необхідністю захисту не тільки від потенційних, а й реальних загроз, що виходять від кримінального оточення небезпечних для засуджених, які постійно перебувають у злочинному середовищі.

Право не наражатися на жорстоке, таке, що принижує людську гідність, поводження чи покарання, а також тортури. Для держави людська гідність засуджених виступає певною духовною основою конструктивного «діалогу» щодо застосування засобів виправлення.

Засуджені мають право на загальних підставах на державне пенсійне забезпечення в старості, при інвалідності, втраті годувальника та в інших випадках, передбачених законодавством України.

Загальногромадянські права, в яких засуджені до позбавлення волі ущемляються частково.

Право засуджених на недоторканність особи. Обмеження права недоторканності 


\section{Адміністративне право}

допускається тільки на підставі закону [7]. До елементів права недоторканості особи відносяться таємниця листування, телефонних переговорів, поштових, телеграфних та інших повідомлень, особиста таємниця. Це право обмежується обов'язковим проведенням: особистих обшуків; обшуків житлових приміщень і особистих речей; цензури одержуваних листів, що відправляються, прослуховуванням телефонних переговорів.

Право на свободу совісті та свободу віросповідання. Законодавець дуже тонко підійшов до вирішення проблеми свободи віросповідання в місцях ізоляції засуджених, закріпивши положення про те, що засудженим гарантуються свобода совісті та свобода віросповідання.

Право на свободу думки та слова є єдиним політичним правом, якого засуджені до позбавлення волі не позбавлені повністю. Засуджені можуть вільно висловити свої думки, судження, жодними правовими актами не встановлено будь-яких обмежень.

Сімейні права. Сам факт утримання в місцях позбавлення волі не тягне припинення цих прав. У зв'язку зі специфікою покарання позбавлення волі засуджені обмежені в підтримці шлюбно-сімейних відносин.

Право на свободу творчості для засуджених, які відбувають покарання в місцях позбавлення волі, обмежується технічними можливостями виправних установ і вимогами режиму, заборонами на користування спеціальними видами інвентарю, техніки та технології, необхідними при здійсненні такої діяльності.

Право на працю. Що стосується особи засуджених, це право спрямоване на створення умов, що забезпечують гідне життя в умовах ізоляції від суспільства та після звільнення. Засуджені мають конституційне право на працю та мають право вимагати від адміністрації виправних установ працевлаштування, щоб набути необхідну спеціальність і заробляти кошти перед звільненням.

I. Б. Мацієвська зазначає, що необхідність залучення засудженого до праці, передусім, є намаганням досягти таких позитивних змін у його особистості, які б сприяли свідомому відновленню соціального статусу засудженого, поверненню до самостійного життя в суспільстві [8, с. 217].

Забезпечення права на відпочинок засуджених до позбавлення волі, на відміну від законослухняних громадян, має певні обмеження, що носять каральний характер. Крім права на відпочинок, працюючим засудженим встановлюються й інші умови, наприклад, щорічна відпустка.

Право засуджених на захист від безробіття. Чинні кримінально-виконавчі законодавства України не містять $з$ цього приводу жодної норми, яка хоча 6 побічно обмежувала осіб, які відбувають покарання, в цьому праві.

Право на освіту. Право на освіту засуджених, які відбувають покарання у вигляді позбавлення волі, в тому числі набуття теоретичних знань і практичних умінь вважається їхнім обов'язком.

Загальногромадянсъкі права, у яких засуджені до позбавлення волі повністю обмежені.

Політичні права. Кримінально-виконавче законодавство України не містить прямої вказівки на політичні права засуджених.

Право на участь в управлінні справами держави. У період відбування покарання засуджені піддаються суттєвому обмеженню права на участь в управлінні справами держави.

Право на об'єднання. Режим у виправних установах виключає можливість реалізації цього права.

Право на свободу пересування, право на вибір місия перебування та місия проживання. Відповідно до кримінально-виконавчого законодавства засудженим забороняється порушувати лінію охорони об'єктів або межі території виправних установ, виходити без дозволу адміністрації за межі ізольованих ділянок.

Загальні спещіальні права засуджених до позбавлення волі. Важливим компонентом прав засуджених до позбавлення волі, що надає особливий статус, є спеціальні права засуджених. Специфікою спеціальних прав є те, що вони не мають аналога в за- 
гальногромадянських правах, носять самостійний характер, не дублюють права законослухняних громадян і обумовлені фактом перебування особи у виправній установі.

Інша особливість спеціальних прав полягає в тому, що зміст не залежить від галузевих прав громадян. Зміна змісту не тягне перетворення прав інших законослухняних громадян і навпаки. Суб'єктами спеціальних прав можуть бути тільки засуджені, які відбувають покарання у вигляді позбавлення волі.

В узагальненому вигляді до загальних спеціальних прав засуджених до позбавлення волі відповідно до кримінально-виконавчого законодавства можна віднести: право на придбання засудженими продуктів харчування та предметів першої необхідності; право на короткострокові та тривалі побачення; право на отримання посилок, передач; право на листування, право отримувати перекази грошових коштів і за рахунок коштів, що знаходяться на особових рахунках, здійснювати перекази грошових коштів близьким родичам; право на телефонні розмови; право на перегляд кінофільмів і телепередач, прослуховування радіопередач; право на придбання i зберігання літератури та письмового приладдя, право на матеріально-побутове забезпечення, право звертатися 3 клопотанням про помилування.

Особливі спечіальні права засуджених до позбавлення волі. Певні категорії засуджених наділяються такими правами залежно від виду виправної установи, де відбувають покарання, статі, соціального стану, поведінки, стану здоров'я, відбуття певної частини строку позбавлення волі, громадянства. У деяких випадках особливі спеціальні права виникають, коли засуджених обмежують у деяких загальних спеціальних правах.

До особливих спеціальних прав засуджених до позбавлення волі відповідно до кримінально-виконавчого законодавства можна віднести: право на проживання 3 сім'єю; право на спільне проживання з дітьми; право мати при собі грошові кошти; право на прогулянку; право на пересуван- ня без конвою; право на виїзди за межі виправних установ; право на звернення 3 клопотанням про відстрочку відбування покарання, звільнення від відбування покарання або про заміну, не відбутої частини покарання більш м'яким видом покарання; право підтримувати зв'язок 3 дипломатичними представництвами та консульськими установами своїх держав в Україні.

До цієї категорії прав належать: відстрочка відбування покарання; умовнодострокове звільнення від відбування покарання; звільнення засудженого від подальшого відбування покарання. Засуджений, у якого є психічний розлад, що перешкоджає відбуванню покарання, засуджений, який захворів на іншу тяжку хворобу, що перешкоджає відбуванню покарання, мають право звернутися до суду 3 клопотанням про звільнення від подальшого відбування покарання.

Право підтримувати зв'язок 3 дипломатичними представництвами та консульськими установами своїх держав в Україні. Перелік прав засуджених іноземців і осіб без громадянства має свої особливості. Вони користуються правами, які встановлені міжнародними договорами, законодавством про правове становище іноземних громадян і осіб без громадянства, 3 вилученнями і обмеженнями, передбаченими кримінальним, кримінально-виконавчим законодавством [9]. Це означає, що іноземним громадянам та особам без громадянства під час відбування покарання у вигляді позбавлення свободи гарантуються природні права людини, забезпечуються рівні умови утримання, передбачаються додаткові права. Зокрема, це право на користування рідною мовою; право давати пояснення та вести листування, звертатися 3 пропозиціями, заявами та скаргами рідною мовою, якою вони володіють, а в необхідних випадках користуватися послугами перекладача.

Засуджені до позбавлення волі мають право підтримувати зв'язок 3 дипломатичними представництвами та консульськими установами своїх держав, а громадяни держав, що не мають дипломатичних 


\section{Адміністративне право}

представництв і консульських установ, 3 дипломатичними представництвами держав, що взяли охорону їхніх інтересів, або з міжнародними органами, що займаються захистом засуджених.

\section{Висновки}

Засуджені до позбавлення волі, ставши суб'єктом пенітенціарних правовідносин, володіють деякими загальногромадянськими правами в повному обсязі (право на життя, право на особисту безпеку), ущемляються в реалізації загальногромадянських прав певною мірою (право на недоторканість особи, право на творчість), позбавляються деяких загальногромадянських прав (політичні права), але наділяються спеціальними правами, які не впливають на загальний цивільний статус законослухняних громадян.

Спеціальні права засуджених до позбавлення волі визначають специфіку відбування такого виду покарання. Серед них виділяються загальні, якими наділені всі засуджені до позбавлення волі, та особливі, якими наділяються певні категорії засуджених. Права засуджених мають певну специфіку, що вимагають індивідуального підходу до їх реалізації.

\section{Мітература}

1. Колос А. С. Правовий статус засуджених у національному кримінально-виконавчому законодавстві. Право та державне управління. 2019. № 4. С. 106-110.

2. Корнякевич-Танасійчук В. Ю. Спеціальний правовий статус засуджених. Право і суспільство. 2019. № 1. С. 143-147.

3. Мерник А. М., Кузьміна В. О., Бурлаков Б. М. Обмеження прав і свобод людини в сучасних умовах: теоретичний i практичний аспекти. Юридичний науковий електронний журнал. 2020. № 2. C. 42-46.

4. Журавська 3. В. Міжнародні стандарти реалізації права засуджених до позбавлення волі на гуманне ставлення та повагу їхньої людської гідності. Міжнародний юридичний вісник: актуальні проблеми сучасності (теорія та практика). 2019. Випуск 14. С. 117-125.
5. Краснокутський О. В. Міжнародно-правові механізми забезпечення прав засуджених до позбавлення волі: дис. ... канд. юрид. наук: спец.: 12.00.08. Харків, 2019. 201 с.

6. Корнякевич-Танасійчук В. Ю. Кримінально-виконавча політика України: автореф. дис. ... д-ра юрид. наук: спец.: 12.00.08. Київ, 2019. 39 с.

7. Кримінально-виконавчий кодекс України : Закон України від 11.07.2003 р.№ 1129-IV / Відомості Верховної Ради України. 2004. № 3-4. Ст. 21.

8. Мацієвська I. Б. Особливості залучення до праці засуджених до позбавлення волі на контрагентських об'єкта. Юридичний науковий електронний журнал. 2019. № 2. С. 214-218.

9. Про правовий статус іноземців та осіб без громадянства : Закон України від 22.09.2011 р. № 3773-VI / Відомості Верховної Ради України. 2012. № 19-20. Ст. 179/

\section{References}

1. Kolos A. S. Pravovyy status zasudzhenykh u natsional'nomu kryminal'novykonavchomu zakonodavstvi. Pravo ta derzhavne upravlinnya. 2019. № 4. S. 106110 .

2. Kornyakevych-Tanasiychuk V. YU. Spetsial'nyy pravovyy status zasudzhenykh. Pravo i suspil'stvo. 2019. № 1. S. 143-147.

3. Mernyk A. M., Kuz'mina V. O., Burlakov B. M. Obmezhennya prav i svobod lyudyny v suchasnykh umovakh: teoretychnyy i praktychnyy aspekty. Yurydychnyy naukovyy elektronnyy zhurnal. 2020. № 2. S. 42-46.

4. Zhuravs'ka Z. V. Mizhnarodni standarty realizatsiyi prava zasudzhenykh do pozbavlennya voli na humanne stavlennya ta povahu yikhn'oyi lyuds'koyi hidnosti. Mizhnarodnyy yurydychnyy visnyk: aktual'ni problemy suchasnosti (teoriya ta praktyka). 2019. Vypusk 14. S. 117-125.

5. Krasnokut's'kyy O. V. Mizhnarodnopravovi mekhanizmy zabezpechennya prav zasudzhenykh do pozbavlennya voli: dys. ... kand. yuryd. nauk: spets.: 12.00.08. Kharkiv, 2019. $201 \mathrm{~s}$.

6. Kornyakevych-Tanasiychuk V. YU. Kryminal'no-vykonavcha polityka Ukrayiny: 


\begin{tabular}{|c|}
\hline $\begin{array}{l}\text { основних складників нормативной бази кримі } \\
\text { нально-виконавчого права щодо регулювання } \\
\text { та захисту прав громадян, засуджених до по } \\
\text { завлення волі в Украӥні. Розглянуто основн } \\
\text { положення кримінально-правового законодав } \\
\text { ства, що визначають зміст правового стату } \\
\text { су засуджених і становлять його структуру }\end{array}$ \\
\hline
\end{tabular}

avtoref. dys. ... d-ra yuryd. nauk: spets.: 12.00.08. Kyyiv, 2019. $39 \mathrm{~s}$.

7. Kryminal'no-vykonavchyy kodeks Ukrayiny : Zakon Ukrayiny vid 11.07.2003 r. № 1129-IV / Vidomosti Verkhovnoyi Rady Ukrayiny. 2004. № 3-4. St. 21.

\section{SUMMARY}

The article considers the classification of the rights of convicts serving sentences in the context of national and international norms of rights on the basis of modern scientific approaches to the classification of legal acts in the field of human rights, determining the main components of the regulatory framework of criminal executive law. regulation and protection of the rights of citizens sentenced to imprisonment in Ukraine. The main provisions of criminal law that determine the content of the legal status of convicts and constitute its structure are considered. The analysis of the legal bases of the status of convicts in Ukraine is carried out, the general civil and special rights of convicts are outlined.

Key words: rights, convict, imprisonment, legal status, penitentiary institution, international standards, foreigners.

8. Matsiyevs'ka I. B. Osoblyvosti zaluchennya do pratsi zasudzhenykh do pozbavlennya voli na kontrahent.s'kykh ob'yekta. Yurydychnyy naukovyy elektronnyy zhurnal. 2019. № 2. S. 214-218.

9. Pro pravovyy status inozemtsiv ta osib bez hromadyanstva : Zakon Ukrayiny vid 22.09.2011 r. № 3773-VI / Vidomosti Verkhovnoyi Rady Ukrayiny. 2012. № 19-20. St. 179. 